\title{
ハウスダスト中元素濃度の変動要因
}

\author{
峡戸 孝也 ${ }^{1)}$, 高木 麻衣 ${ }^{2)}$, 吉永 淳 ${ }^{2}$, \\ 田中 敦3), 瀬山 春彦3), 柴田 康行 ${ }^{3)}$ \\ ${ }^{1)}$ 北里大学医療衛生学部 ( ₹ 228-8555 神奈川県相模原市北里 1-15-1) \\ ${ }^{2}$ 東京大学新領域創成科学研究科（†277-8563 千葉県柏市柏の葉5-1-5) \\ 3)独立行政法人国立環境研究所（テ305-8506 茨城県つくば市小野川16-2)
}

[平成20年 9 月 19 日受付, 平成21年 1 月 7 日受理]

\section{Factors Related to Elemental Variation in House Dust}

\author{
Takaya KAIDO $^{1)}$, Mai TAKAGI ${ }^{2)}$, Jun YOSHINAGA ${ }^{2}$, \\ Atsushi TANAKA ${ }^{3}$, Haruhiko SEYAMA ${ }^{3)}$ and Yasuyuki SHIBATA ${ }^{3)}$ \\ ${ }^{1)}$ Allied Health Sciences, Kitasato University \\ (1-15-1 Kitasato, Sagamihara, Kanagawa 228-8555) \\ ${ }^{2)}$ Department of Environmental Studies, University of Tokyo \\ (5-1-5 Kashiwanoha, Kashiwa, Chiba 277-8563) \\ ${ }^{3)}$ National Institute for Environmental Studies \\ (16-2 Onogawa, Tsukuba, Ibaraki 305-8506)
}

[Received September 19, 2008; Accepted January 7, 2009]

\begin{abstract}
Summary
Concentrations of 25 elements ( $\mathrm{Al}, \mathrm{Ba}, \mathrm{Ca}, \mathrm{Cd}, \mathrm{Co}, \mathrm{Cr}, \mathrm{Cs}, \mathrm{Cu}, \mathrm{Fe}, \mathrm{K}, \mathrm{Mg}, \mathrm{Mn}, \mathrm{Mo}, \mathrm{Na}$, $\mathrm{Ni}, \mathrm{P}, \mathrm{Pb}, \mathrm{S}, \mathrm{Sb}, \mathrm{Sn}, \mathrm{Sr}, \mathrm{Ti}, \mathrm{U}, \mathrm{V}, \mathrm{Zn}$ ) in house dust samples of households in Tokyo Metropolitan Area and Chugoku district in Japan were measured and the source(s) of their household-to-household variations were analyzed with particular focus on those of $\mathrm{Pb}$ variation. Vacuum cleaner dusts were supplied from 2-6 households from each of 8 apartment buildings and one pair of adjacent houses constructed by the same house-maker (total number of samples: 27). House dust samples, prepared by passing the cleaner dust through $250 \mu \mathrm{m}$ mesh, were acid-digested and element concentrations were determined by ICP emission spectrometry and ICP mass spectrometry. Inter-household variation in elemental concentration, as well as that of elemental ratio to Al calculated to correct for the effect of outdoor soil/dust, was large. Elemental ratio to $\mathrm{Al}$ did not differ among the buildings for all of the elements except for $\mathrm{Mg}$, indicating element level in house dust varies more due to "dweller's factor" than to locality and/or materials for the construction of the buildings. The result of correlation analysis indicated paint and general heavy metal pollution involving $\mathrm{Cd}, \mathrm{Cu}, \mathrm{Ni}$ or $\mathrm{Zn}$ of unknown source as source of $\mathrm{Pb}$ in house dust, which was consistent with the result of the previous study. Additionally, $\mathrm{Pb}-\mathrm{Sn}$ correlation indicated solder as another source while no candidate source emerged with regard to highly significant $\mathrm{Pb}-\mathrm{Mo}$ correlation.
\end{abstract}

Key words: house dust, element, inter-household variation, between-building variation, withinbuilding variation 


\section{1. はじめに}

ハウスダストがある種の化学物質の曝露源として重要 である可能性があることはすでに欧米では認識されてい る。特に室内の滞在時間が長い, hand-to-mouth 行動な どにより非意図的に摂食する可能性が高い等の理由で, ハウスダストは化学物質への感受性が高い乳幼児の曝露 媒体として, わが国でも今後ますます注目されるものと 考えられる。

これまで欧米でもっとも重点的に調査研究されてきた 八ウスダスト中の化学成分は鉛 $(\mathrm{Pb})$ である。かつて $\mathrm{Pb}$ を含有するペンキを住居の塗装に使用していたアメリカ などの国では, 塗装面の劣化に伴って剥離したペンキ片 が室内に直接落下・粉末化したり，住居外壁等から剥離 したペンキ片が建物周辺の土壤を污染し，その土畩が室 内に持ち込まれたりする経路によってハウスダストが $\mathrm{Pb}$ によって污染され，それが小児の $\mathrm{Pb}$ 曝露源として重 要であるという認識吕から, 八ウスダスト中 $\mathrm{Pb}$ の調査研 究が充実していた。

わが国では， $\mathrm{Pb}$ 含有ペンキを家屋の塗装に用いるこ とがなかったことや，土足で室内に入ることがないこと から, 欧米でのハウスダストの状況とは異なるものと推 測されるが，最近の研究によると，わが国のハウスダス 卜中 $\mathrm{Pb}$ は地殼存在度に比して10倍程度濃縮しているこ と ${ }^{2)}$ ，および日本人小児の $\mathrm{Pb}$ 曝露源として大きな寄与を している可能性 ${ }^{3)}$ が指摘されている。さらに $\mathrm{Pb}$ 安定同位 体比を用いた調査でも，小児の血中 $\mathrm{Pb}$ の起源としてハ ウスダストが疑われるケースがあることが報告されてい る ${ }^{4)}$ 。一方，日本人小児にとってハウスダストが $\mathrm{Pb}$ 以外 の有害重金属類の曝露源として大きな寄与を持つかどう かについて，わが国のハウスダスト中各種元素濃度の情 報が限られている現在では明らかでない。中村らは $\mathrm{Pb}$ 以外にも $\mathrm{Cu}, \mathrm{Cd}, \mathrm{Zn}$ などのハウスダスト中存在レベル は地款存在度より 1 桁高いことを報告している2。

ところで，ハウスダスト中の $\mathrm{Pb}$ 濃度にはサンプリン グした世帯間で大きなばらつきがある。Ishibashiらは, 日本各地の41世帯から採取したハウスダスト（粒径 $<$ $250 \mu \mathrm{m} ）$ の $\mathrm{Pb}$ 濃度は12.9〜 466 mg $/ \mathrm{kg}$ の範囲であり, 変 動係数が106\%であることを報告している（算術平均 $94.5 \mathrm{mg} / \mathrm{kg}$, 標準偏差 $100 \mathrm{mg} / \mathrm{kg})^{5)}$ 。このような大きな世 帯間変動が何に由来するのか, 八ウスダストの研究がほ とんどなされていないわが国では，現在のところ明らか でない。Ishibashi らはさらに, 日本各地の世帯からサン プリングしたハウスダスト中 $\mathrm{Pb}$ 濃度と, その世帯の近 隣土壤および空枠（室外側）にたまったダストの $\mathrm{Pb}$ 濃 度との関連を調べ，これら室外試料との間に正の相関が あることを見いだした5゙。この結果は，ハウスダストの $\mathrm{Pb}$ 濃度には室外から入り込む土壤やダストの影響もあるこ
とを示すものではあるが, 見出された相関は弱いので, 他にももっと大きな変動要因があるものと考えられる。

本研究では, ハウスダスト中の $\mathrm{Pb}$ 濃度に見られる大き い世帯間変動の要因を絞り达むためのアプローチとして, 同じ集合住宅建物の異なる部屋 (世帯) からサンプリン グしたハウスダストの $\mathrm{Pb}$ 分析を行い，それらの濃度の世 带間変動に占める建物内変動と建物間変動の相対的な大 きさについて検討した。建物間変動の方が大きい場合に は，建物のある地域や建物そのもの（建材等）に由来する 変動の方が大きいことを示し, 建物内変動の方が大きい 場合には, 居住者の持ち込んだもの（家具, 雑貨等) やラ イフスタイルの方が変動に大きな寄与をすることを示す ものと考えた。また， ハウスダスト中 $\mathrm{Pb}$ の起源推定の一 方法として，他元素との関連を調べるのにあわせ，八ウ スダスト中他元素 (24元素) の濃度レベル, 世帯間変動, 変動要因についても, $\mathrm{Pb}$ 同様に検討した。

\section{2. 試料と方法}

\section{ハウスダスト試料}

本研究で分析対象としたハウスダスト試料は首都圈お よび中国地方の合計 27 世帯に依頼して収集した。この二 地域内の 4 箇所の集合住宅の同じ棟から 2 世帯ずつ, 1 箇所から 3 世帯, 2 箇所から 4 世帯ずつ, 1 箇所から 6 世帯（異なる 3 棟から 2 世帯ずつサンプリングしたが, 同じ敷地内に隣接する間取り・内装などほぼ同一の 3 棟 なので 1 箇所とした）の計 25 世帯，さらに同じハウス メーカーによって同時期に建築された隣接する戸建て建 売住宅 2 世帯の計27世帯である。対象とした建物は築 8〜39年であり, すべて住宅地域にあった。鉛污染源と なるような施設などの存在は確認されていない。なお世 帯構成は一人暮らしから家族 4 人まで含まれる。それら の家庭に予め調査の目的，方法などを説明した上で掃除 機に蓄積したごみの提供および生活に関する質問票への 回答に関して承諾を得た。2007年 8 月31日に各家庭で通 常使用している掃除機のフィルターの交換（紙パック方 式，集塵箱の排出（サイクロン式）を行ってもらい，9 月 1 日から30日までに蓄積した掃除機ごみを東京大学に 送付してもらった。

送付された掃除機ごみは，全量を $2 \mathrm{~mm}$ および $250 \mu \mathrm{m}$ の開き目のステンレス製ふるいを通して 3 粒径に分画し た。これまでのわれわれの調査方式5) と同様に2 $50 \mu \mathrm{m} の$ ふるいを通過した粉状のダスト（繊維状物質除外）を小 児の手に付着しやすいハウスダストとして本研究の分析 対象とした。なお，対象とした 27 世帯で 1 ケ月間に蓄積 したごみ全体の重さは0.6〜68g (中央值 $28 \mathrm{~g}$ ), うち

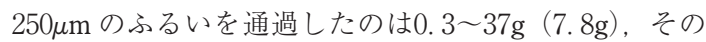
うち纎維状物質の塊状の埃や頭髪をピンセットを用いて 
除外した, 本研究で「ハウスダスト」と呼ぶ画分は0.2 $34 \mathrm{~g}(6.6 \mathrm{~g})$ であった。

ハウスダスト試料はよく混合した後，一部（100〜 $300 \mathrm{mg})$ を $110^{\circ} \mathrm{C}, 2$ 時間加熱した後の重量減少分を水分 含量とした。残りの一部を元素分析に用いた。水分含量 は6.1土1.3\%（2.9〜8.7\%）であった。

\section{元素分析}

ハウスダスト試料は既報と同様, 約 $100 \mathrm{mg}$ をテフロン ビーカーにとり，ホットプレート上で硝酸（電子工学 用, 関東化学) - 過塩素酸 (有害金属測定用, 関東化学) フッ化水素酸 (AA-100, 多摩化学) による分解 2 .5)を行っ た。過塩素酸の白煙を出しながらほぼ乾固した残椬を $0.3 \mathrm{~mol} / \mathrm{l}$ 硝酸 (超高純度, 関東化学) で $50 \mathrm{~g}$ に希釈して 分解液とし， $0.45 \mu \mathrm{m}$ の酢酸セルロース製フィルター (ミニザルト, ザルトリウス) でろ過後, ICP 発光分析法 (ICAP-750, 日本ジャレルアッシュ) で $\mathrm{Al}, \mathrm{Ba}, \mathrm{Ca}, \mathrm{Cr}$, $\mathrm{Cu}, \mathrm{Fe}, \mathrm{K}, \mathrm{Mg}, \mathrm{Mn}, \mathrm{Na}, \mathrm{Ni}, \mathrm{P}, \mathrm{S}, \mathrm{Sr}, \mathrm{Ti}, \mathrm{V}, \mathrm{Zn}$ 濃度を, 分解液をさらに50倍希釈して ICP 質量分析法 (7500ce, アジレントテクノロジー) で Cd（測定質量数 111), Co (59), Cs (133), Mo (95), Pb (208), Sb (121 および123)，Sn（118および120），U（238）の濃度を定量 した。ハウスダストの元素濃度はすべて水分含量を補正 し, 乾燥重量あたりで求めた。

以上のハウスダスト試料の分析は, すべてのサンプル について二重測定を行った。二つの定量值の差を, 定量 值の平均值で除した值の中央值は，測定対象としたほと んどすべての元素について $20 \%$ 未満であった。例外は $\mathrm{Cu}$ (中央值25\%), $\mathrm{Ni}(32 \%)$ であった。このレベルの 不均一性が粒径 $250 \mu \mathrm{m}$ 以下のハウスダス卜試料にはある
ことを念頭に置きながらも，二重測定結果の平均值を もってその世帯のハウスダスト中元素濃度として解析に 使用した。

また, 米国National Institute of Standard and Technology (NIST) が頒布するハウスダスト認証標準物質（SRM 2583 Indoor Dust）を試料と同様に分解，測定し，測定の 精度管理を行った。たたし本研究で測定した元素のうち, 認証值は $\mathrm{Cr}, \mathrm{Cd}, \mathrm{Pb}$ にの与えられており, それぞれ $80 \pm 20,7.3 \pm 3.7,85.9 \pm 7.2 \mathrm{mg} / \mathrm{kg}$ に対し, 本研究で得ら

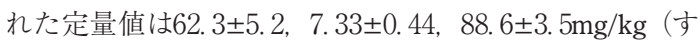
べて $\mathrm{n}=8$ ) と, 平均值は認証值の不確かさの幅の中に 入った。Crはやや低めの定量值が得られたが, これはこ の CRMには酸に不溶なクロマイトなどの $\mathrm{Cr}$ が含まれる ためかもしれない。

\section{統計解析}

ハウスダスト中元素濃度は二重測定の差によらず平均 をとり，各世带ハウスダストの元素濃度とした。土壤 などの混入による濃度変動があることを勘案し, 八ウス ダスト中元素濃度は $\mathrm{Al}$ 濃度との比をとったうえで，建 物（棟）内変動と建物間変動の大きさを Kruskal-Wallis 検定によって比較した。各種記述統計，分散分析，相関

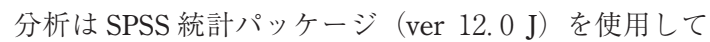
行った。

\section{3. 結果と考察}

\section{1 ハウスダスト中の元素濃度}

Table 1 に測定した25元素の算術平均濃度及び中央 值を一覧した。ほとんどすべての元素で世帯間のばらつ

Table 1 Element concentrations in house dust samples $(n=27) \#$

\begin{tabular}{|c|c|c|c|c|c|c|c|c|c|}
\hline & $\mathrm{Al}$ & $\mathrm{Ba}$ & $\mathrm{Ca}$ & $\mathrm{Cd} *$ & Co* & $\mathrm{Cr}$ & Cs* & $\mathrm{Cu}$ & $\mathrm{Fe}$ \\
\hline Unit & $\%$ & $\mathrm{mg} / \mathrm{kg}$ & $\%$ & $\mathrm{mg} / \mathrm{kg}$ & $\mathrm{mg} / \mathrm{kg}$ & $\mathrm{mg} / \mathrm{kg}$ & $\mathrm{mg} / \mathrm{kg}$ & $\mathrm{mg} / \mathrm{kg}$ & $\%$ \\
\hline Median & 1.81 & 208 & 2.56 & 1.20 & 5.29 & 61.0 & 0.828 & 267 & 1.03 \\
\hline Mean & 1.97 & 323 & 2.80 & 1.36 & 6.11 & 75.5 & 1.12 & 616 & 1.25 \\
\hline $\mathrm{SD}$ & 0.91 & 477 & 1.49 & 0.75 & 2.79 & 42.5 & 0.84 & 1452 & 0.63 \\
\hline \multirow[t]{2}{*}{ Min-Max } & $0.706-3.89$ & $77.8-2571$ & $0.938-7.92$ & $0.17-3.07$ & $2.79-12.1$ & $26.3-203$ & $0.403-3.75$ & $69.8-7715$ & $0.536-3.69$ \\
\hline & $\mathrm{K}$ & $\mathrm{Mg}$ & $\mathrm{Mn}$ & Mo* & $\mathrm{Na}$ & $\mathrm{Ni}$ & $\mathrm{P}$ & $\mathrm{Pb} *$ & S \\
\hline Unit & $\%$ & $\%$ & $\mathrm{mg} / \mathrm{kg}$ & $\mathrm{mg} / \mathrm{kg}$ & $\%$ & $\mathrm{mg} / \mathrm{kg}$ & $\mathrm{mg} / \mathrm{kg}$ & $\mathrm{mg} / \mathrm{kg}$ & $\%$ \\
\hline Median & 0.832 & 0.421 & 261 & 2.26 & 0.905 & 57.3 & 868 & 55.3 & 0.486 \\
\hline Mean & 0.939 & 0.469 & 290 & 5.06 & 0.913 & 67.1 & 994 & 120 & 0.512 \\
\hline SD & 0.385 & 0.245 & 129 & 14.8 & 0.250 & 30.4 & 570 & 269 & 0.155 \\
\hline \multirow[t]{2}{*}{ Min-Max } & $0.444-2.17$ & $0.170-1.05$ & $116-617$ & $0.793-78.7$ & $0.368-1.37$ & $32.0-175$ & $337-2840$ & $18.0-1428$ & $0.269-0.800$ \\
\hline & $\mathrm{Sb} *$ & Sn* & $\mathrm{Sr}$ & $\mathrm{Ti}$ & U* & V & $\mathrm{Zn}$ & & \\
\hline Unit & $\mathrm{mg} / \mathrm{kg}$ & $\mathrm{mg} / \mathrm{kg}$ & $\mathrm{mg} / \mathrm{kg}$ & $\%$ & $\mathrm{mg} / \mathrm{kg}$ & $\mathrm{mg} / \mathrm{kg}$ & $\mathrm{mg} / \mathrm{kg}$ & & \\
\hline Median & 8.12 & 19.6 & 72.3 & 0.149 & 0.422 & 27.6 & 717 & & \\
\hline Mean & 9.75 & 28.7 & 75.4 & 0.158 & 0.668 & 34.5 & 1168 & & \\
\hline $\mathrm{SD}$ & 4.85 & 25.1 & 33.3 & 0.039 & 0.453 & 20.6 & 1357 & & \\
\hline Min-Max & $1.93-22.7$ & $8.09-114$ & $27.2-170$ & $0.099-0.283$ & $0.215-1.53$ & $9.20-79.4$ & $235-5923$ & & \\
\hline
\end{tabular}


きが大きく，平均值が中央值を上回っていた。飛び離れ た少数の大きな值がある, 対数正規分布型の分布である ことを示している。濃度レベルについては，元素によっ て\%オーダーから $1 \mathrm{mg} / \mathrm{kg}$ 以下のものまで多様であっ た。測定した中では Ca が最高值で， $\mathrm{Al} ， \mathrm{Fe}$ までが\% オーダー以上であった。Fig. 1に中村らが報告した，首 都圈10軒の家庭から採取した掃除機ごみの19元素の測定 結果 ${ }^{2}$ と比較した。中村らの結果は $2 \mathrm{~mm}$ 以下の粒径を 6 粒径分画に分けて測定した值すべて（6粒径 $\times 10$ 軒= 60）の中央值であり，本研究とは異なる粒径のダストを 含んだ值なので厳密には比較できないが，元素濃度は非 常に類似していた。 $\mathrm{Pb}$ 濃度については, 本研究と同様に $250 \mu \mathrm{m}$ 以下の分画を測定した Ishibashi らの結果（中央值 $54.1 \mathrm{mg} / \mathrm{kg}$, 平均 $\pm \mathrm{SD}=94.5 \pm 100 \mathrm{mg} / \mathrm{kg}, \mathrm{n}=41)^{5)}$ とよ く一致していた。Aung らの報告した首都圈の家庭のハ ウスダスト $(<150 \mu \mathrm{m}$ 分画 $)$ 中鉛濃度の算術平均值 $117 \mathrm{mg} / \mathrm{kg}(\mathrm{n}=21)^{3)}$ とも一致した。しかし, 本研究では 最大で $1,428 \mathrm{mg} / \mathrm{kg}$ というきわめて大きな值が見い出さ れている。Cd も同様に Ishibashi らの中央値 $0.932 \mathrm{mg} / \mathrm{kg}$ 5)とよく一致した。以上のように, Table 1 に示した元素 濃度は, 世带毎のばらつきは大きいものの, 代表值とし ては，これまで報告されているわが国の八ウスダスト中 濃度とよく一致したものである。

中村らと同様に，ハウスダスト中元素濃度をサンプル

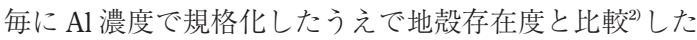
Enrichment Factor（EF，下式）の中央值を示したのが
Fig. 2である。

$$
E F e=\frac{[M e / A l]_{\text {indoorddust }}}{[\mathrm{Me} / \mathrm{Al}]_{\text {crustal }}}
$$

なおこの式で $E F e$ はある元素 $e$ の $\mathrm{EF}, \mathrm{Me}$ は八ウス夕゙ スト中のその元素の濃度あるいは地殼存在度(6), $A l$ は八 ウスダスト中 $\mathrm{Al}$ 濃度あるいは地殼 $\mathrm{Al}$ 濃度である。 $\mathrm{EF}$ が 10付近を超える元素 $\mathrm{P}, \mathrm{S}, \mathrm{Cu}, \mathrm{Zn}, \mathrm{Cd}, \mathrm{Pb}$ は中村らの 報告したものと同様であった。本研究で新たに測定対象 とした元素のうち, Mo, Sn, Sbの EFが10以上で, 特に $\mathrm{Sb}$ 㧍よび $\mathrm{Sn}$ の $\mathrm{EF}$ が高かった（それぞれ239，55）。わ が国の大気粉塵中 $\mathrm{Sb}$ の $\mathrm{EF}$ が大きいことはすでに報告さ れており7，Sbの環境中レベルは人為污染の影響を大き く受けていることは明らかである。ハウスダスト中の $\mathrm{EF}$ もききということは，室外環境由来の污染が室内 に入り込んでいるという可能性がまず考えられる。一方 $\mathrm{Sb}$ はプラスチックの難燃処理に多用されている他, Sn はハンダとしての使用がよく知られているが，各種プラ スチックやハンダを多用した電子部品が室内環境には多 く存在することを考慮すると, Sb P Sn の発生源が室内 に存在する可能性も十分ある。

\section{2 ハウスダスト中元素濃度の世帯間変動}

27世帯の元素濃度のばらつきを, 算術平均值で標準偏 差を除した変動係数 (Coefficient of variation, CV : 単位 は\%）で表すと，元素によって25\%から292\%まで大き

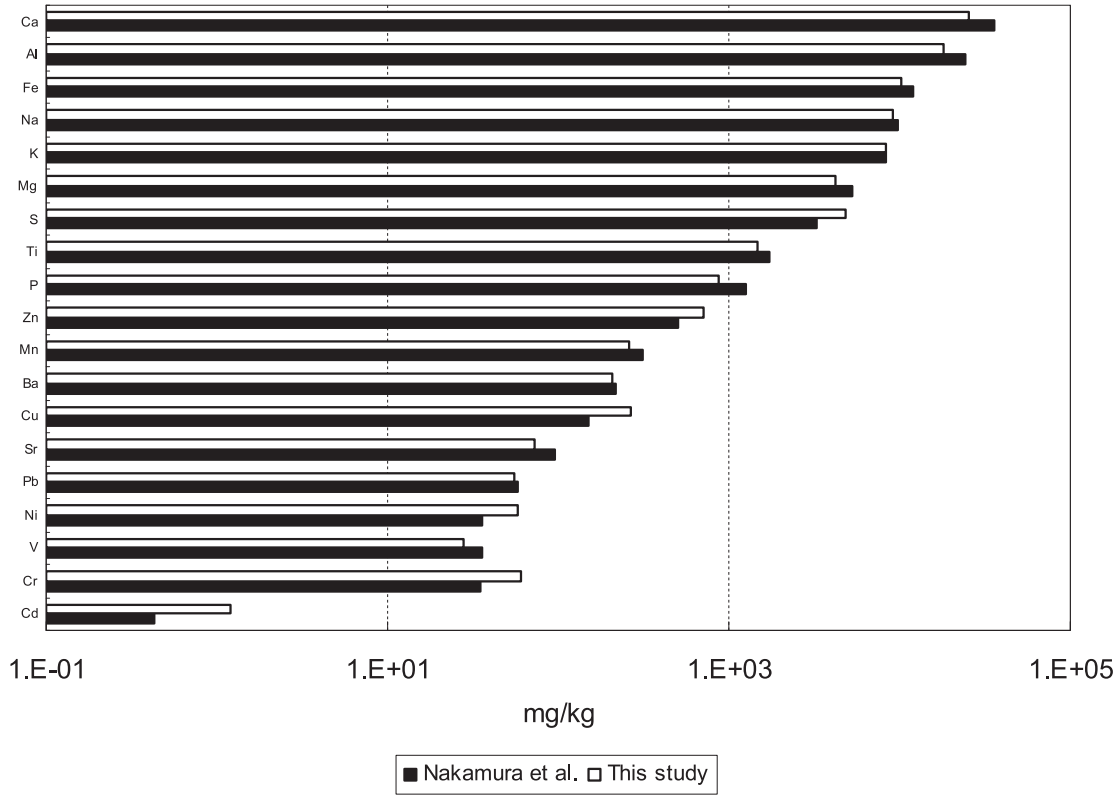

Fig. 1 Comparison of element concentrations in house dust obtained in this study and those reported in the previous study (Nakamura et al., 2008) 
な変動幅をもつ。CV とハウスダスト中元素濃度の中央 值との関連を示したものが Fig. 3である。CV が100\%以 下の元素に限ってみると，中央值が大きくなるにつれて 緩やかに CV が低下し，その相関係数は有意であった $(\mathrm{r}=-0.569, \mathrm{p}<0.01)$ 。主成分をなす元素ほど世带間 のばらつきが小さいということである。一方，CVが
100\%を越える元素には $\mathrm{Zn} ， \mathrm{Ba} ， \mathrm{~Pb} ， \mathrm{Cu}, \mathrm{Mo}$ があり， $\mathrm{Zn}$ から Mo の順に大きな $\mathrm{CV}$ 值となった。これら 5 元素 は，八ウスダスト中の濃度レベルから推定されるよりも 大きいばらつきをもつ，ということである。このうち Zn 以外は大きく離れた值を示した世帯は 1 軒のみであり （Zn は 3 軒），それぞれの外れ值を除外すると CV は47〜

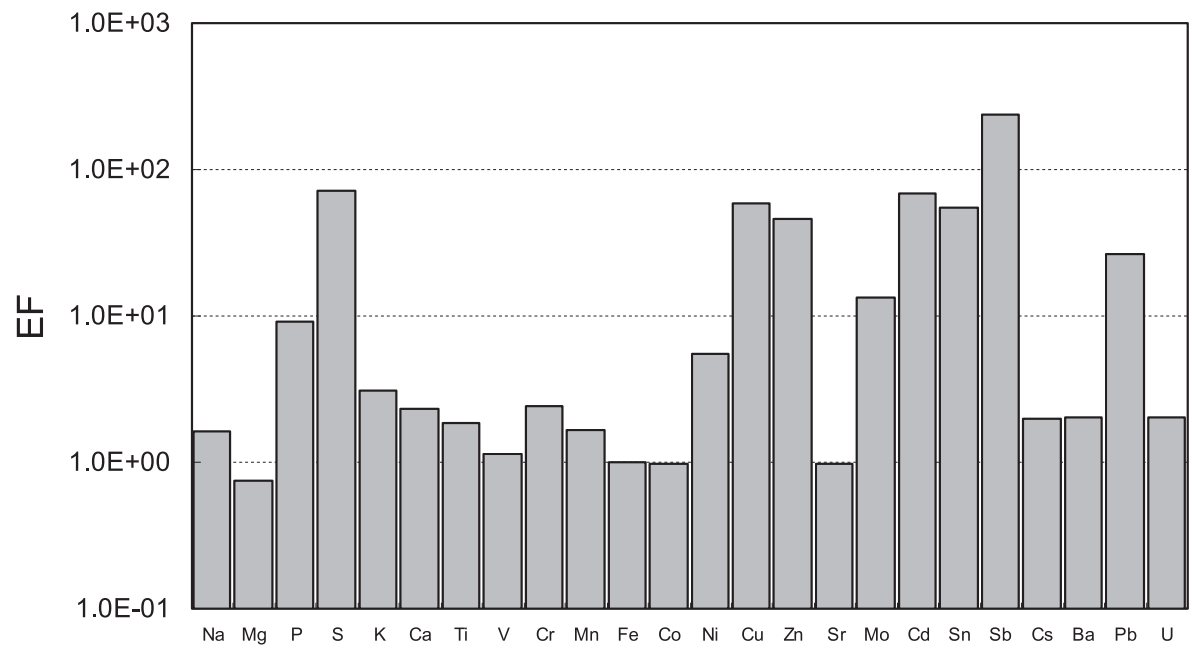

Fig. 2 Enrichment factor (EF) of the elements in house dust analyzed in this study. For the definition of EF, see text

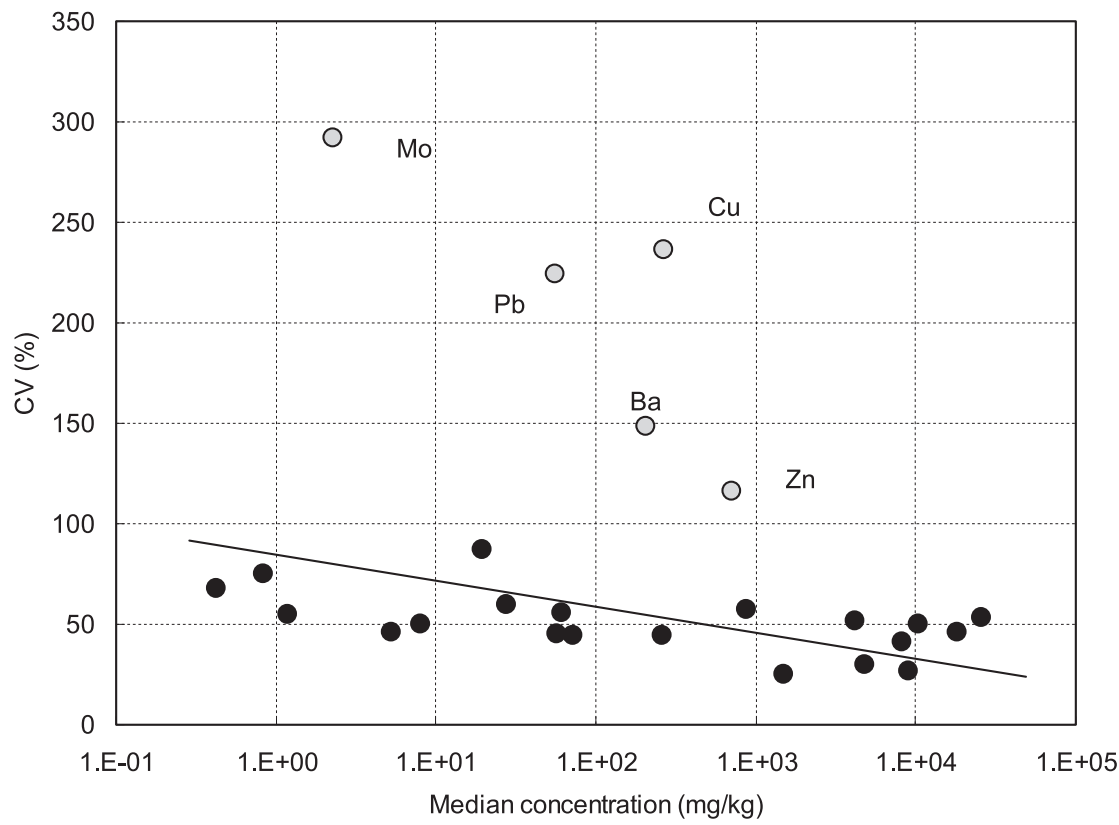

Fig. 3 Relathionship between the median concentration in house dust and coefficient of variation (CV) of the concentration of the elements analyzed in this study 
93\%と，他の元素とほぼ同じ程度まで下がった。なお， 他の世帯と大きく異なる Mo, Pb 濃度を示した世帯は同 一であったが， $\mathrm{Ba}, \mathrm{Cu}$ が外れ值を示した世帯はどちら もこの $\mathrm{Mo} / \mathrm{Pb}$ が外れた世帯とは異なる世帯であった。こ のように $\mathrm{Ba}, \mathrm{Cu}$ は各元素単独に高濃度に含有する何か, $\mathrm{Mo}$ と $\mathrm{Pb}$ は両元素を高濃度に含有する何か, がそれぞれ ハウスダストに混入していた。

中村らはハウスダスト中元素濃度の変動のもっとも大 きな要因として土壤等の混入があることを因子分析の結 果から推定した2)。その結果に基づき，本研究で求めた 元素濃度と土壤の主要元素である $\mathrm{Al}$ との比をとって世 帯間変動を計算すると, Fe や Mn などの CV は濃度より $\mathrm{Al}$ 比の方が小さくなったが, 他のほとんどの元素は必ず しも $\mathrm{Al}$ 比の方が小さい $\mathrm{CV}$ とはならず，ほとんど濃度の $\mathrm{CV}$ とかわらないもの $(\mathrm{Cd}, \mathrm{Cu}, \mathrm{Ni}, \mathrm{P}$ など $)$ むしろ $\mathrm{Al}$ 比の方が大きくなるもの（Ba, $\mathrm{S}, \mathrm{Sb}$ な゙）があった。 $\mathrm{Pb}$ 濃度の $\mathrm{CV}$ (224\%) は $\mathrm{Al}$ 比をとると $151 \%$ に，やや低 下した。ハウスダストへの土壤等の混入率の変動がハウ スダスト中元素濃度の変動の大きな要因である元素は $\mathrm{Fe} \mathrm{Pn}$ などに限られ, $\mathrm{Pb}$ な゙は中程度の大きさの要因 であるが, 他の元素は土壤混入以外の寄与が大きいこと を示唆する結果である。しかしながら以下の統計解析で は, 土壤などの混入による変動の影響を取り除くため に, 元素濃度と $\mathrm{Al}$ 濃度の比を用いることとした。

\section{3 ハウスダスト中 $\mathrm{Pb}$ 濃度レベルと他元素濃度レベ ルとの関連}

ハウスダストに含まれる各種元素・ $\mathrm{Al}$ 比同士の相関関 係をスピアマンの順位相関分析によって調べた結果, き わめて多くの元素間に統計的に有意な正の相関関係が見 いだされた。中村らも同様にハウスダスト中の多数の元 素濃度間に有意な相関を見いだし，それらの関連を整理 するために因子分析を行った2)。今回のデータは試料数
が少ない $(\mathrm{n}=27)$ ので, 因子分析には適さないと判断 し, ハウスダスト中の起源の解明がもっとも必要と考え られる $\mathrm{Pb}$ を中心として他元素との関連を整理した。

$\mathrm{Pb}$ 濃度と有意な相関を示したのは, Mo $(r=0.814$, $\mathrm{p}<0.001), \mathrm{Cd}(\mathrm{r}=0.649, \mathrm{p}<0.001), \mathrm{Sn}(\mathrm{r}=0.601$, $\mathrm{p}<0.01), \mathrm{Cu}(\mathrm{r}=0.578, \mathrm{p}<0.01), \quad \mathrm{S}(\mathrm{r}=0.567, \mathrm{p}$ $<0.01), \mathrm{Sb}(\mathrm{r}=0.564, \mathrm{p}<0.01), \mathrm{Cr}(\mathrm{r}=0.519, \mathrm{p}$ <0.01）であり，これ以外にも $\mathrm{Ni}, \mathrm{P}, \mathrm{Ti}, \mathrm{Zn}$ が $\mathrm{r}=0.4$ 以上の有意な相関係数 $(\mathrm{p}<0.05)$ を示した。これらの 相関関係はすべて正の相関であり，相関のあるぺア同士 の元素は起源が類似している可能性を示すものと考えら れる。中村ら ${ }^{2)}$ が指摘したように $\mathrm{Cr}, \mathrm{S}, \mathrm{Ti}$ は塗料に特徵 的な元素群であり, 今回のデータで $\mathrm{Pb} / \mathrm{Al}$ と正の相関を 持つということは八ウスダスト中 $\mathrm{Pb}$ の一部は塗料に由 来する, という彼らの考察と合致する。また中村らは, ハウスダスト中 $\mathrm{Pb}$ は $\mathrm{Cd}, \mathrm{Ni}, \mathrm{Cu}, \mathrm{Zn}$ など, $\mathrm{EF}$ の大き い人為污染重金属類ともある程度挙動が一致することを 報告しているが，今回の結果もこれと矛盾しない。すな わち本研究結果は, 中村らの結果とともに, ハウスダス ト中の $\mathrm{Pb}$ の起源として塗料および「その他の人為重金 属污染」(詳細は不明であるが) を示唆している。

本研究で初めて測定された Mo や $\mathrm{Sn}$ と $\mathrm{Pb}$ とのやや強 い正の相関関係（Fig. 4）が何を表すのか現時点では不 明である。前述したように Mo と $\mathrm{Pb}$ の両元素を非常に高 い濃度で含有するハウスダストのデータが含まれること は事実であるが，ここで用いている解析手法は順位相関 であるから外れ值の影響は受けにくいはずで, 実際にこ の世帯のデータを除外しても $\mathrm{r}=0.792$ と相関の強さは ほとんど変わらない。 $\mathrm{Mo}-\mathrm{Pb}$ の関連は今回対象とした世 帯全体に普遍的に見られるもののようであるが，何に由 来しているのかは不明である。一方 $\mathrm{Sn}-\mathrm{Pb}$ の相関は, 電 子機器類等に使用されているハンダに由来する室内污染 を示しているのかもしれない。 $\mathrm{Pb} / \mathrm{Al}$ と $\mathrm{Sb} / \mathrm{Al}$ との正の相
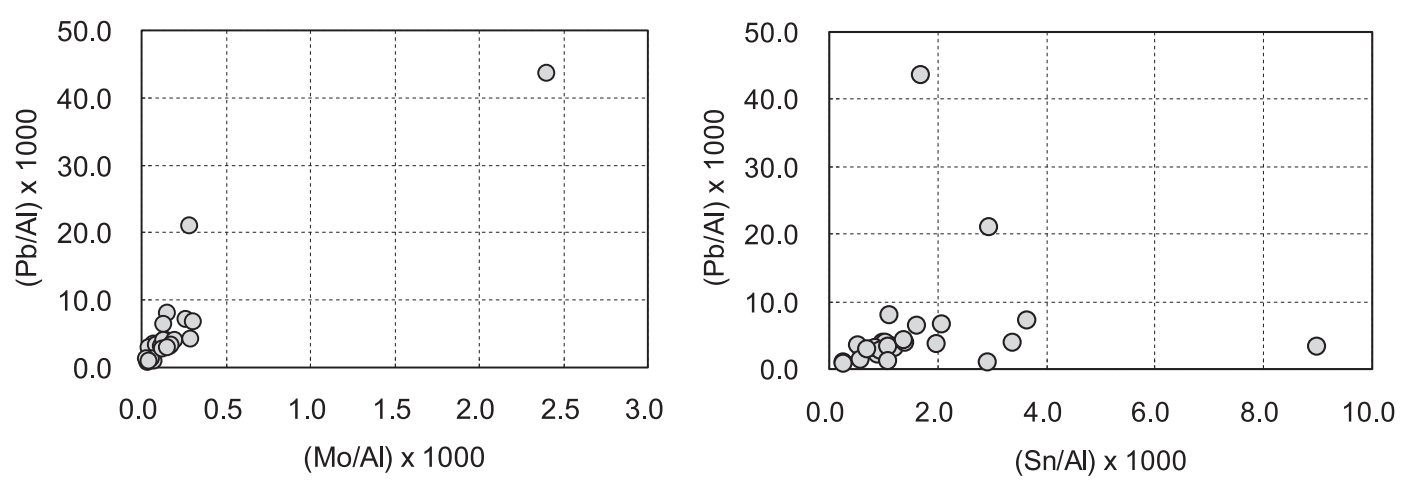

Fig. 4 Correlation of elemental ratio to $\mathrm{Al}$ in house dust. Left, $\mathrm{Mo} / \mathrm{Al}$ vs $\mathrm{Pb} / \mathrm{Al}$. Right, $\mathrm{Sn} / \mathrm{Al} \mathrm{vs} \mathrm{Pb} / \mathrm{Al}$. $\mathrm{Both}$ of the Spearman rank correlation coefficients ( $r=0.814$ and 601 , respectively) are significant at $p=0.001$ 
関も相関係数がおおきかった。 $\mathrm{Sb}$ は $\mathrm{Pb}$ 以外とも $\mathrm{Cu}$, $\mathrm{Cd}, \mathrm{Mo}, \mathrm{Na}, \mathrm{Ni}, \mathrm{S}, \mathrm{Ti}, \mathrm{Zn}$ などの多様な元素と0.6〜 0.7 強い正の相関を示しており，ハウスダスト中の $\mathrm{Sb}$ の起源は多様なものであると推定できる。したがって $\mathrm{Sb}-\mathrm{Pb}$ の相関から $\mathrm{Pb}$ の起源について特定することは困 難であるが，プラスチックが一つの候補であると考えら れる。

\section{4 ハウスダスト中元素濃度レベルの建物内変動と建 物間変動}

8 棟の集合住宅及び隣り合った戸建て住宅の計 9 建物 間の元素・ $\mathrm{Al}$ 濃度比を Kruskal-Wallis 検定すると, 建物 間に有意な差が見られたのは $\mathrm{Mg}\left(\chi^{2}=17.68, \mathrm{p}<0.05\right)$ のみであり，その他は $\mathrm{Pb}$ を含め，すべて建物間の差は 有意ではなかった。Fig. 5 に $\mathrm{Mg}$ と $\mathrm{Pb}$ の例を示した。 $\mathrm{Mg}$ 以外で建物間の差が有意でなかったのは， $\mathrm{Pb}$ に典型的 に見られるように，建物内での元素・ $\mathrm{Al}$ 濃度比のばらつ きが大きいために，建物間の差が統計的に有意にならな かったものである。建物間の変動要因を分類すると, 建 物のある地域に由来する要因と建物の建材の違いなどの 要因が考えられる。ここで地域的要因とは, 室外から混 入する土壤・ダス卜類の含有する元素・ $\mathrm{Al}$ 濃度比の地域 的なばらつきがハウスダストに反映するという「室外要 因」である。これに対し，同じ集合住宅の建物内ばらつ きは地域要因や建材などが同一の条件でのばらつきであ るので, 居住者のもちこむ家具類や居住の仕方（ライフ スタイル）による。いわば「居住者要因」と言い換える ことができる。 $\mathrm{Mg}$ 以外の23元素の対 $\mathrm{Al}$ 濃度比の建物間
差が有意にならなかった，という今回の統計解析結果 は，ハウスダスト中のほとんどの元素について，「室外 要因」「建材要因」よりも「居住者要因」のほうが強い変 動要因であることを意味する。

どのような居住者要因によってハウスダスト中の鉛や 他の元素濃度レベルが変動するか, 本研究からは明らか ではないが, 欧米で行われた既往の研究では, 暖房器 具・調理器具のエネルギー源 (石油か電気か), 絨毯の使 用の有無などによってハウスダスト中の重金属類濃度が 変動するとの報告がある ${ }^{8 \sim 10)}$ 。また, これらの報告では, 居住者要因ではないものの, 築年数が古い住居のハウス ダスト中鉛濃度が高い, という結果が共通して得られて いるが，これは1950〜60年代の $\mathrm{Pb}$ 含有塗料の規制前に 建てられた住居には塗料由来の $\mathrm{Pb}$ が混入するから, と いう欧米特有の状況が背景にある。なお本研究の場合, 建物の築年数と $\mathrm{Pb}$ 等元素濃度の間には関連は見られな かった。このように, 現在のところわが国とは習慣等が 異なる欧米での知見しかないので, 今後はわが国のハウ スダスト中元素濃度の変動に寄与する居住者要因の特定 を行う必要がある。

\section{4. 結言}

ハウスダスト中元素濃度は世帯毎に大きなばらつきを 示す。変動要因をなるべく制御するために，同じ集合住 宅の異なる世帯（あるいは隣接する同じ建て売り戸建て 住宅）からハウスダストを採取する，土壤等からの影響 を最小限に抑えるためにハウスダスト中元素濃度を $\mathrm{Al}$
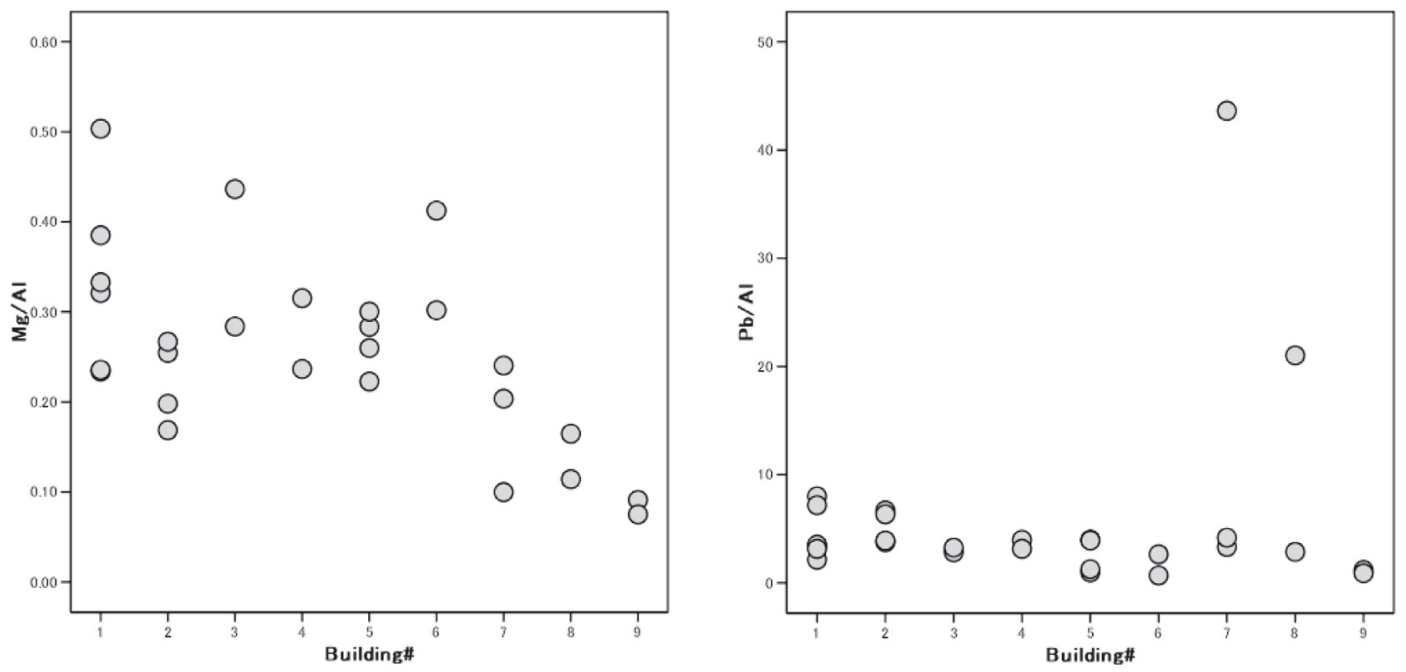

Fig. 5 Elemental ratio to $\mathrm{Al}$ in the house dust samples collected from 2-6 households from each of 9 buildings. Left, $\mathrm{Mg} / \mathrm{Al}$. Right, $\mathrm{Pb} / \mathrm{Al}$. $\mathrm{Mg} / \mathrm{Al}$ had significant variation according to the buildings (KruskalWallis test, $\mathrm{p}<0$. 05 ) but $\mathrm{Pb} / \mathrm{Al}$ did not 
濃度との比をとって表す, などの工夫をしても，Pbをは じめとする本研究で測定対象としたすべての元素で世帯 毎の変動は大きかった。また, 八ウスダスト中元素濃度 レベルには建物間差がみられなかった, という解析結果 を併せて考えても，住居の地理的要因や建材等に由来す る要因（建物間要因）よりも，持ち込まれる家具類やラ イフスタイルなど, 居住者に由来する要因（建物内要 因）のほうがより重要な変動要因であると考えられた。 どのような居住者要因が八ウスダスト中のどのような元 素の存在量に影響を及ぼすのかについて，より詳細な検 討が必要であると考えられる。

八ウスダスト中の $\mathrm{Pb}$ の起源について，本研究では既 報と同様，土壤粒子など室外からの混入，塗料や一般重 金属污染との関連が示唆されたほか, 新たにハンダやプ ラスチックの関与を示唆する元素間関連が見いだされ た。

今後，わが国の一般公衆，特に小児の重金属等曝露評 価にあたり，Pbのように, ハウスダストからの寄与が無 視できない重金属は何であるかが調査され，その次のス テップとして，過剩曝露による健康リスクを低減化する ためのハウスダストへの対策が必要となる場面が生ずる ものと予想される。そのために，八ウスダスト中各種元 素濃度レベルに関する記述的データの蓄積と濃度レベル の変動要因の解明がますます重要になるものと考えられ る。

\section{謝 辞}

掃除機ごみサンプルを提供くださった 27 世帯の方々に 深謝します。本研究の一部は平成19年度卜ステム建材産 業振興財団からの助成金で行われた。

\section{要 約}

わが国の一般家庭のハウスダスト中 $\mathrm{Pb}$ 等元素濃度の 変動要因を探ることを目的として，ハウスダストサンプ ルの分析を行った。同じ集合住宅の複数 $(2 \sim 6)$ 世 带, あるいは同じ八ウスメーカーによる隣接した 2 軒の戸 建て建て売り住宅，合計27世帯に依頼して，2007年 9 月の 1 ケ月間に蓄積した掃除機ごみを入手した。 $250 \mu \mathrm{m}$ のふる いを通してハウスダスト試料とし，混酸分解した後，ICP 発光分析法, ICP 質量分析法で25元素の定量を行った。す べての元素について, 世帯毎のハウスダスト中濃度は大き なばらつきを持っていた。土䁃等室外要因による変動を最 小とするために，八ウスダスト中元素濃度を $\mathrm{Al}$ 濃度で除 して，Al 比として統計解析を行った。建物間（n=9）の
元素濃度レベルの差は, 建物内 $(\mathrm{n}=2 \sim 6)$ のばらつき に比較して大きくなく, 八ウスダスト中 $\mathrm{Pb}$ 等元素濃度 レベルは，建物の存在する地域や建材などよりも，居住 者要因によって主に変動すると考えられた。他元素との 相関分析結果から， ハウスダスト中 $\mathrm{Pb}$ の起源として, 既報と同様に塗料，原因の明確でない一般的な重金属污 染が見出された。さらに，八ウスダスト中の $\mathrm{Pb}-\mathrm{Sn}$ の正 の相関から，ハンダに由来する室内起因の污染の可能性 が考えられたが，もっとも強い相関を示した $\mathrm{Pb}-\mathrm{Mo} の$ 関係が何に起因するのか不明であった。

\section{文 献}

1) IPCS: Environmental Health Criteria 3 Lead. WHO, Geneva (1977)

2）中村有希，高木麻衣，吉永 淳，田中 敦，瀬山春 彦, 柴田康行：日本の室内塵の元素組成と鉛の起 源，室内環境，11，11-20（2008）

3) Aung, N.N., Yoshinaga, J. and Takahashi, J.: Exposure assessment of lead among Japanese children. Environ. Health Prevent. Med. 9, 257-261 (2004)

4）高木麻衣，田宮さやか，吉永 淳，田中 敦，瀬山 春彦，柴田康行，上松あゆ美，加治正行：同位体分 析に基づく日本人小児の鉛曝露源解析, 環境化学, 18, 521-531 (2008)

5) Ishibashi, Y., Yoshinaga, J., Tanaka, A., Seyama, H. and Shibata, Y.: Lead and cadmium in indoor dust in Japanese houses --- Relationship with outdoor sources. 室内環境，11，93-101 (2008)

6）松久幸敬, 赤木 右：「地球科学概説」, 培風館, p75 東京 (2005)

7) Furuta, N., Iijima, A., Kambe, A., Sakai, K. and Sato, K.: Concentrations, enrichment and predominant sources of $\mathrm{Sb}$ and other trace elements in size classified airborne particulate matter collected in Tokyo from 1995 to 2004. J. Environ. Monitor. 7, 1151-1161 (2005)

8) Fergusson, J.E. and Kim, N.D.: Trace elements in street and house dust: sources and speciation. Sci. Total Environ. 100, 125-150 (1991)

9) Tong, S.T.Y.: Indoor and outdoor household dust contamination in Cincinnati, Ohio, USA. Environ. Geochem. Health 20, 123-133 (1998)

10) Rasmussen, P.E., Subramanian, K.S. and Jessiman, B.J.: A multi-element profile of housedust in relation to exterior dust and soils in the city of Ottawa, Canada. Sci. Total Environ. 267, 125-140 (2001) 